\title{
Sistem Pakar Diagnosis Penyakit Gastritis Menggunakan Metode Certainty Factor Berbasis Android
}

\author{
Yudi Eko Windarto ${ }^{1}$, R. Rizal Isnanto ${ }^{2}$, Annas Setiawan ${ }^{3}$ \\ ${ }^{1}$ Departemen Teknik Komputer, Fakultas Teknik, Universitas Diponegoro \\ Jl. Prof. Soedarto, SH, Tembalang, Semarang, Indonesia, e-mail: yudi@live.undip.ac.id \\ ${ }^{2}$ Departemen Teknik Komputer, Fakultas Teknik, Universitas Diponegoro \\ Jl. Prof. Soedarto, SH, Tembalang, Semarang, Indonesia, e-mail: rizal_isnanto@yahoo.com \\ ${ }^{3}$ Departemen Teknik Komputer, Fakultas Teknik, Universitas Diponegoro \\ Jl. Prof. Soedarto, SH, Tembalang, Semarang, Indonesia, \\ e-mail: asetiawan@student.ce.undip.ac.id
}

\section{ARTICLE INFO}

Article history:

Received 17 Maret 2020

Received in revised form 02 May 2020

Accepted 11 May 2020

Available online 30 July 2020

\section{ABSTRACT}

With the increasingly of the modern era, more and more diseases that arise due to human lifestyle and bacterial transmission. One of them is gastritis which occurs because of inflammation that occurs in the lining of the stomach which makes frequent pain in the stomach. From these problems, it is necessary to make an expert system application of gastritis disease which aims to provide information to the public to know the early symptoms of gastritis from an early age. The process of diagnose using the certainty factor method. The Certainty Factor method provides a diagnosis process with symptom $\mathrm{CF}$ values that have been determined by experts so that it provides accurate results from calculations based on symptom CF values chosen by the user. From this research, it produces an expert system application that can diagnose the type of disease with the first test case $98.848 \%$, the second test case $99.8464 \%$ and the third test case with the results of $99.99115264 \%$ correct and in accordance with expert knowledge. System testing is done by using black-box testing that shows the function of each unit of application $100 \%$ successful.

Keywords: Gastritis, expert system, certainty factor, and Android 


\section{Pendahuluan}

Gastritis adalah peradangan selaput lambung yang disebabkan oleh kombinasi dari berbagai macam faktor, termasuk infeksi Helicobacter pylori (H. pylori) [1]. Kondisi tersebut dapat menjadi masalah akut atau kronis yang meningkatkan risiko pada kondisi lain, seperti radang lambung, perdarahan, atau kanker [2]. Pada beberapa kasus medis, gastritis adalah salah satu masalah kesehatan yang selalu muncul pada masyarakat [3]. Gastritis berhubungan dengan masalah saluran pencernaan [4]. Gejala yang muncul adalah adanya rasa nyeri pada daerah epigastrium. Sehingga para dokter memerlukan adanya diagnosis lebih lanjut, dimana untuk memastikan gastritis memerlukan pemeriksaan penunjang seperti endoskopi [5] [6].

Gastritis merupakan gangguan yang paling banyak ditemui pada klinik karena diagnosisnya hanya berdasarkan gejala klinis [7]. Penyakit tersebut sering dijumpai muncul secara mendadak yang biasanya ditandai dengan gejala rasa mual dan muntah, nyeri, perdarahan, rasa lemah, nafsu makan menurun, atau sakit kepala [8]. Pembagian klinis gastritis secara garis besar dibagi menjadi dua jenis yaitu gastritis akut dan gastritis kronis. Gratistis akut merupakan kelainan klinis akut yang jelas penyebabnya dengan tanda dan gejala yang khas, biasanya ditemukan sel inflamasi akut [9].

Sistem Pakar (Expert System) adalah program berbasis pengetahuan yang menyediakan solusi-solusi dengan kualitas pakar untuk masalah - masalah dalam suatu wilayah yang spesifik [10]. Sistem pakar merupakan program komputer yang meniru proses pemikiran dan pengetahuan pakar dalam menyelesaikan suatu masalah tertentu. Implementasi sistem pakar banyak digunakan dalam bidang psikologi karena sistem pakar dipandang sebagai cara penyimpanan pengetahuan pakar pada bidang tertentu dalam program komputer sehingga keputusan dapat diberikan dalam melakukan penalaran secara cerdas [11].

Pembuatan aplikasi sistem pakar di bidang kedokteran ini nantinya dapat mendeteksi penyakit gastritis yang dijalankan pada platform Android. Pada penelitian sebelumnya banyak yang telah membuat sistem pakar gastritis ini. Namun, belum ada yang membuat dalam bentuk perangkat bergerak. Sistem pakar berbasis Android ini memudahkan pengguna dalam mengaksesnya dimana dan kapan saja.

\section{Metode Penelitian}

\section{A. Akuisisi Pengetahuan}

Akuisisi pengetahuan adalah tahapan akumulasi, transfer, dan transformasi keahlian dalam menyelesaikan masalah dari sumber pengetahuan ke dalam program komputer. Dengan kata lain, pada tahapan ini dilakukan perancangan basis pengetahuan untuk sistem pakar.

Certainty Factor merupakan salah satu teknik pengambilan keputusan untuk mengatasi ketidakpastian. Faktor kepastian ini diusulkan oleh shortliffe pada tahun 1975 untuk mengakomodasi ketidakpastian pemikiran seorang pakar [12].Tim pengembangan mencatat bahwa dokter menganalisa informasi dengan ungkapan seperti mungkin, kemungkinan besar, hampir pasti dan sebagainya [13]. Penggunaan metode certainty factor ini untuk menggambarkan tingkat keyakinan pakar terhadap masalah yang sedang dihadapi.

Bentuk rumus dasar certainty factor dari sebuah aturan JIKA E MAKA H ditunjukkan dalam rumus berikut [13]:

Dimana :

$$
\mathrm{CF}(\mathrm{H}, \mathrm{e})=\mathrm{CF}(\mathrm{E}, \mathrm{e}) * \mathrm{CF}(\mathrm{H}, \mathrm{E})
$$

$\mathrm{CF}(\mathrm{E}, \mathrm{e})$ adalah certainty factor evidence $\mathrm{E}$ yang dipengaruhi oleh evidence $\mathrm{e}$

$\mathrm{CF}(\mathrm{H}, \mathrm{E})$ adalah certainty factor hipotesis dengan asumsi evidence diketahui dengan pasti, yaitu ketika CF $(\mathrm{E}, \mathrm{e})=1$

$\mathrm{CF}(\mathrm{H}, \mathrm{e})$ adalah certainty factor hipotesis yang dipengaruhi oleh evidence e

Jika semua bukti pada antecedent diketahui dengan pasti, maka persamaan rumus untuk certainty factor adalah

Dimana :

$$
\mathrm{CF}(\mathrm{H}, \mathrm{e})=\mathrm{CF}(\mathrm{H}, \mathrm{E})
$$


CF (H,E) merupakan nilai kepastian yang diberikan oleh pakar terhadap suatu aturan.

$\mathrm{CF}(\mathrm{E}, \mathrm{e})$ merupakan nilai kepercayaan yang diberikan oleh pengguna terhadap gejala yang dialaminya.

Untuk penyakit yang memiliki gejala lebih dari satu, maka dapat menggunakan persamaan sebagai berikut.

Dimana :

$$
\text { CFcombineCF }[H, E]_{1,2}=C F[H, E] 1+C F[H, E] 2 \times\left(1-[H,]_{1}\right)
$$

- $C F c o m b i[H, E] 1,2$ : nilai certainty factor yang memiliki gejala 1 dan 2 pada suatu penyakit.

- $\mathrm{CF}[\mathrm{E}] 1 \quad$ : nilai certainty factor suatu penyakit kerpercayaan dengan gejala 1.

$\mathrm{CF}[\mathrm{E}] 2 \quad$ : nilai certainty factor suatu penyakit kerpercayaan dengan gejala 2

Sumber pengetahuan pada tahapan akuisisi pengetahuan dalam perancangan sistem pakar pada penelitian ini diperoleh dari seorang pakar (dalam hal ini adalah dokter spesialis penyakit dalam) RSUD Kota Salatiga yaitu dr. Kuadiharto, Sp.PD.FINASIM. Perancangan akuisisi pengetahuan ini dimulai dengan membuat tabel yang berisikan informasi mengenai jenis gejala dan jenis penyakitnya. Data-data dari gejala penyakit gastritis dibuat dalam bentuk tabel yang berisi kode gejala dan daftar jenis gejala sebagai bahan deteksi sistem yang dapat dilihat pada Tabel 1.

Tabel 1. Jenis Penyakit dan gejala Penyakit

\begin{tabular}{cc}
\hline Kode Gejala & Gejala Penyakit \\
\hline G1 & Konsumsi obat dosis tinggi \\
(bukan obat gastritis) \\
G2 & Mual dan Muntah \\
G3 & Badan Pucat \\
G4 & Perut terasa sakit ketika kosong \\
G5 & Sering Bersendawa \\
G6 & Nyeri terasa panas dan perih di \\
& perut bagian ulu hati \\
G7 & Buang air besar dengan tinja \\
G8 & berwarna hitam \\
G9 & Perut terasa kembung \\
G10 & Kehilangan selera makan \\
G11 & Muntah Darah \\
G12 & Nyeri pada perutl lebih dari 6 \\
& bulan \\
\hline
\end{tabular}

Dalam aplikasi sistem pakar ini terdapat 2 jenis penyakit gastritis yang akan dideteksi yaitu gastritis akut dan gastritis kronis. Data-data penyakit tersebut dapat dilihat pada Tabel 2 yang berisi kode jenis penyakit dan jenis penyakit.

Tabel 2. Daftar jenis penyakit

\begin{tabular}{cc}
\hline Kode Jenis Penyakit & Jenis Penyakit \\
\hline P1 & Gastritis Akut \\
P2 & Gastritis Kronis \\
\hline
\end{tabular}

Tabel relasi yang digunakan pada aturan produksi sistem. Tabel ini berisi data jenis penyakit yang direalisasikan dengan gejala-gejala yang merupakan pengetahuan dari pakar. Tabel relasi berfungsi untuk melakukan atau mengambil keputusan berdasarkan metode pengambilan

TRANSFORMATIKA Vol. 18, No. 2, July $2020: 36-55$ 
keputusan yang dibangun oleh aplikasi sistem pakar. Tabel relasi gejala dan penyakit ditunjukkan pada Tabel 3.

Tabel 3. Relasi gejala dan penyakit

\begin{tabular}{ccc}
\hline Kode Gejala & Kode Penyakit & \\
\hline G1 & P1 & $\checkmark$ \\
G2 & $\checkmark$ & $\checkmark$ \\
G3 & $\checkmark$ & $\checkmark$ \\
G4 & $\checkmark$ & $\checkmark$ \\
G5 & $\checkmark$ & $\checkmark$ \\
G6 & $\checkmark$ & $\checkmark$ \\
G7 & $\checkmark$ & \\
G8 & $\checkmark$ & $\checkmark$ \\
G9 & $\checkmark$ & $\checkmark$ \\
G10 & $\checkmark$ & $\checkmark$ \\
G11 & & $\checkmark$ \\
G12 & & \\
\hline
\end{tabular}

Data jenis penyakit dan gejala yang sudah direalisasikan maka dibuat Tabel 4 yaitu tabel bobot nilai cf antara jenis penyakit dan data gejala dengan nilai faktor kepastian certainty factor $(C F)$ yang digunakan untuk menunjukkan ukuran kepastian terhadap suatu fakta. Bobot nilai CF ditunjukkan seperti Tabel 4 di bawah ini.

Tabel 4. Bobot nilai CF

\begin{tabular}{ccc}
\hline Kode Gejala & Penyakit & Nilai CF \\
\hline \multirow{2}{*}{ G1 } & Gastritis Akut & 0,6 \\
& Gastritis Kronis & 0,6 \\
G2 & Gastritis Akut & 0,8 \\
& Gastritis Kronis & 0,6 \\
G3 & Gastritis Akut & 0,4 \\
& Gastritis Kronis & 0,4 \\
G4 & Gastritis Akut & 0,6 \\
& Gastritis Kronis & 0,6 \\
G5 & Gastritis Akut & 0,4 \\
& Gastritis Kronis & 0,4 \\
G6 & Gastritis Akut & 0,6 \\
G7 & Gastritis Kronis & 0,8 \\
& Gastritis Akut & 0,8 \\
G8 & Gastritis Kronis & 0,4 \\
& Gastritis Akut & 0,4 \\
G9 & Gastritis Akut & 0,4 \\
G10 & Gastritis Kronis & 0,6 \\
G11 & Gastritis Kronis & 0,6 \\
G12 & Gastritis Kronis & 0,8 \\
\hline
\end{tabular}

Tabel 5 menunjukkan interpretasi tingkat keyakinan yang diperoleh dari dr. Kuadiharto, Sp.PD.FINASIM selaku pakar yang digunakan saat menentukan nilai CF gejala pada setiap penyakit. 
Tabel 5. Tingkat Keyakinan nilai CF gejala

\begin{tabular}{cc}
\hline $\begin{array}{c}\text { Tingkat Keyakinan } \\
\text { Pakar }\end{array}$ & $\begin{array}{c}\text { Nilai CF } \\
\text { Gejala }\end{array}$ \\
\hline Kemungkinan tidak & 0,2 \\
Kemungkinan & 0,4 \\
Kemungkinan besar & 0,6 \\
Hampir Pasti & 0,8 \\
Pasti & 1 \\
\hline
\end{tabular}

\section{B. Perancangan Proses Kerja}

Tahap awal untuk desain rancangan proses kerja adalah menentukan seluruh pola aplikasi melalui sebuah bagan perancangan aplikasi yang berisi masing masing bagian dari aplikasi yang akan dibuat. Gambar 1 menunjukan bagan perancangan aplikasi

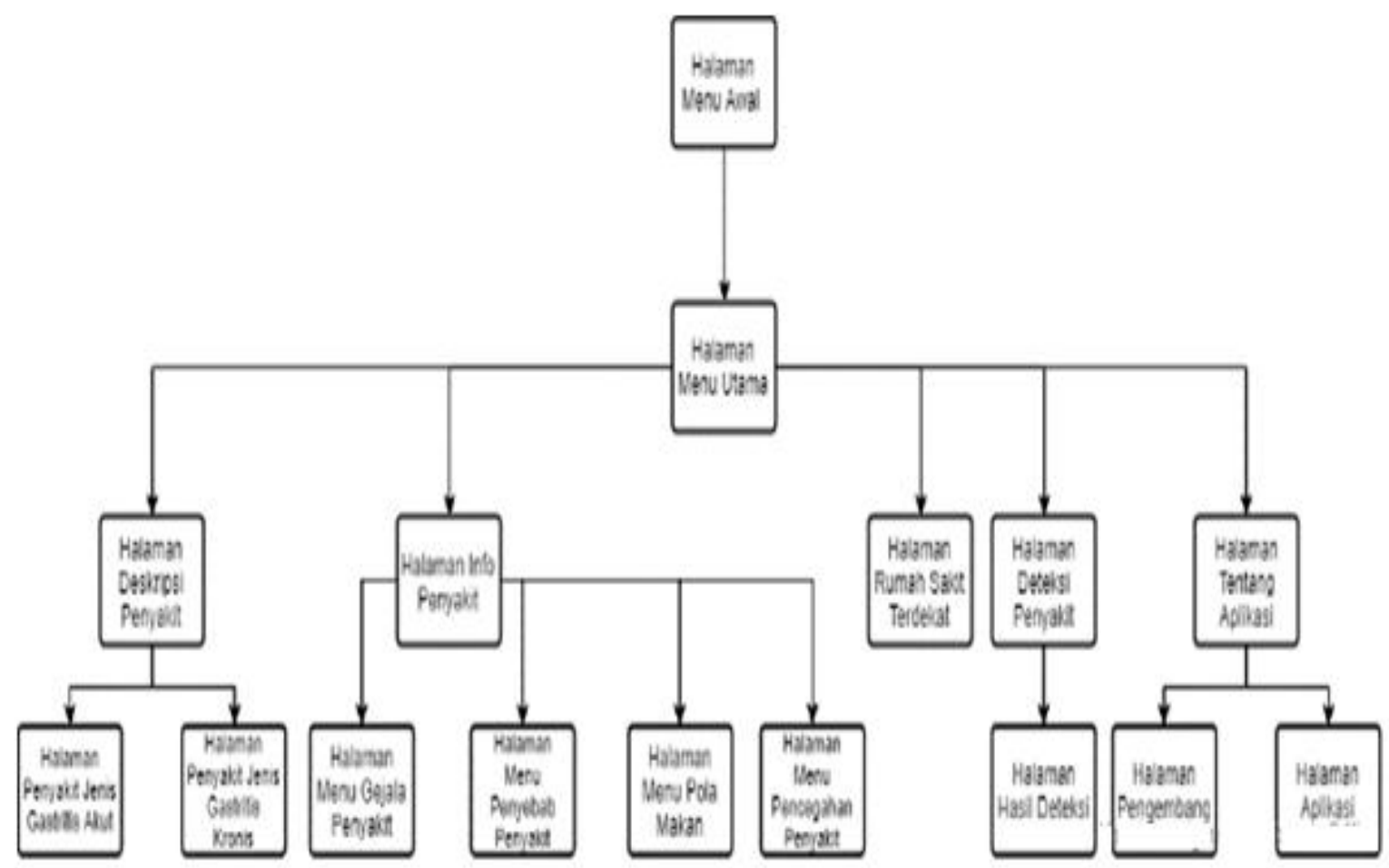

Gambar 1. Bagan perancangan aplikasi

Dari bagan di atas dapat dilihat bahwa masing-masing bagian aplikasi dapat dijelaskan dengan baik. Kemudian dilanjutkan dengan pembuatan diagram use case, diagram aktivitas dan diagram sequence.

Diagram aktivitas merupakan diagram yang memodelkan aliran kerja atau workflow dari urutan aktifitas dalam suatu proses yang mengacu pada diagram use case yang ada.

TRANSFORMATIKA Vol. 18, No. 2, July $2020: 36-55$ 


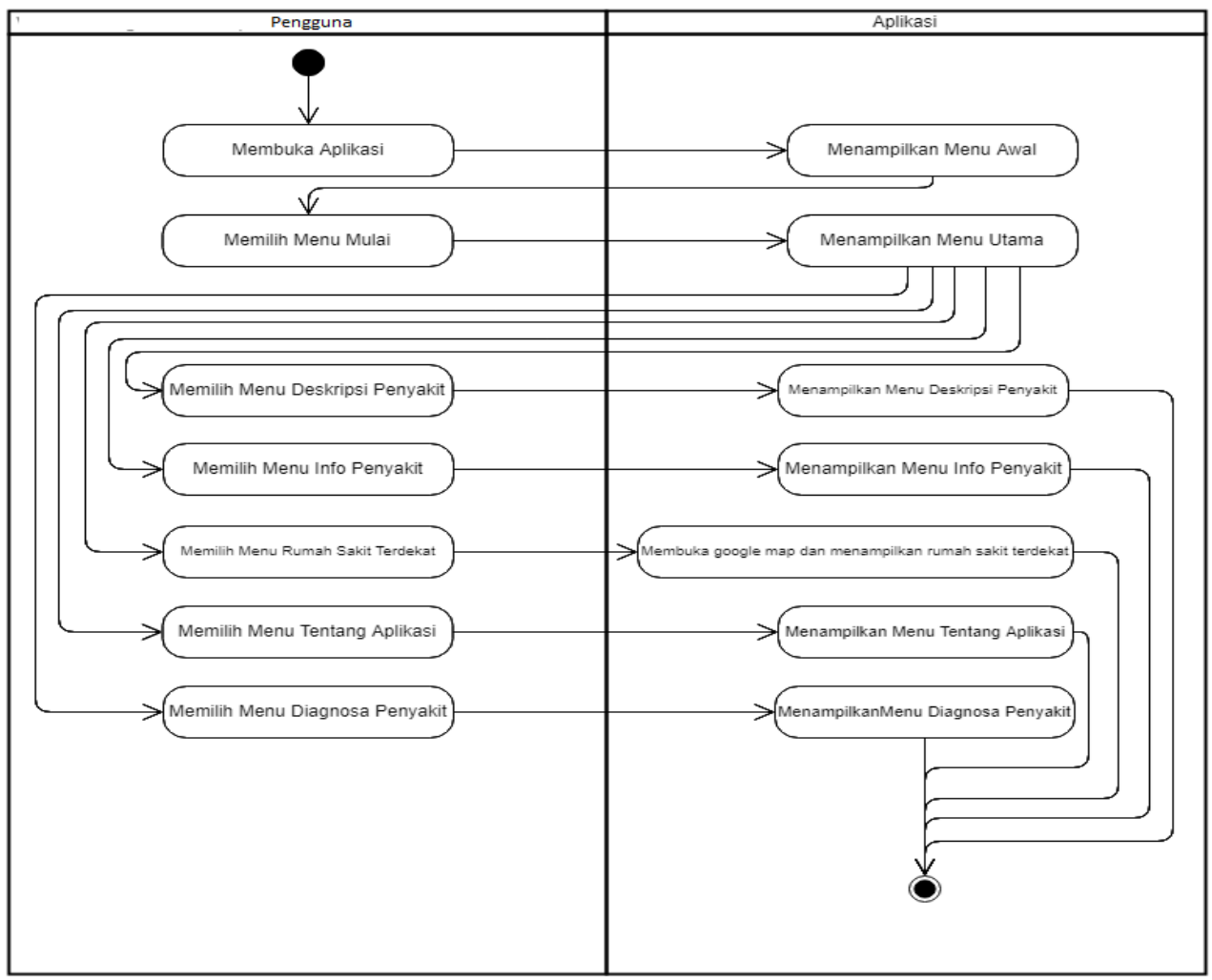

Gambar 2. Diagram Aktivitas

Diagram use case digunakan untuk memodelkan dan menyatakan unit fungsi atau layanan yang disediakan oleh sistem ke pengguna. Dalam use case ini hanya ada satu pemakai yaitu pengguna aplikasi. Pengguna dapat berinteraksi dan dapat melakukan tindakan ke dalam sistem yang sudah memiliki skenario didalamnya

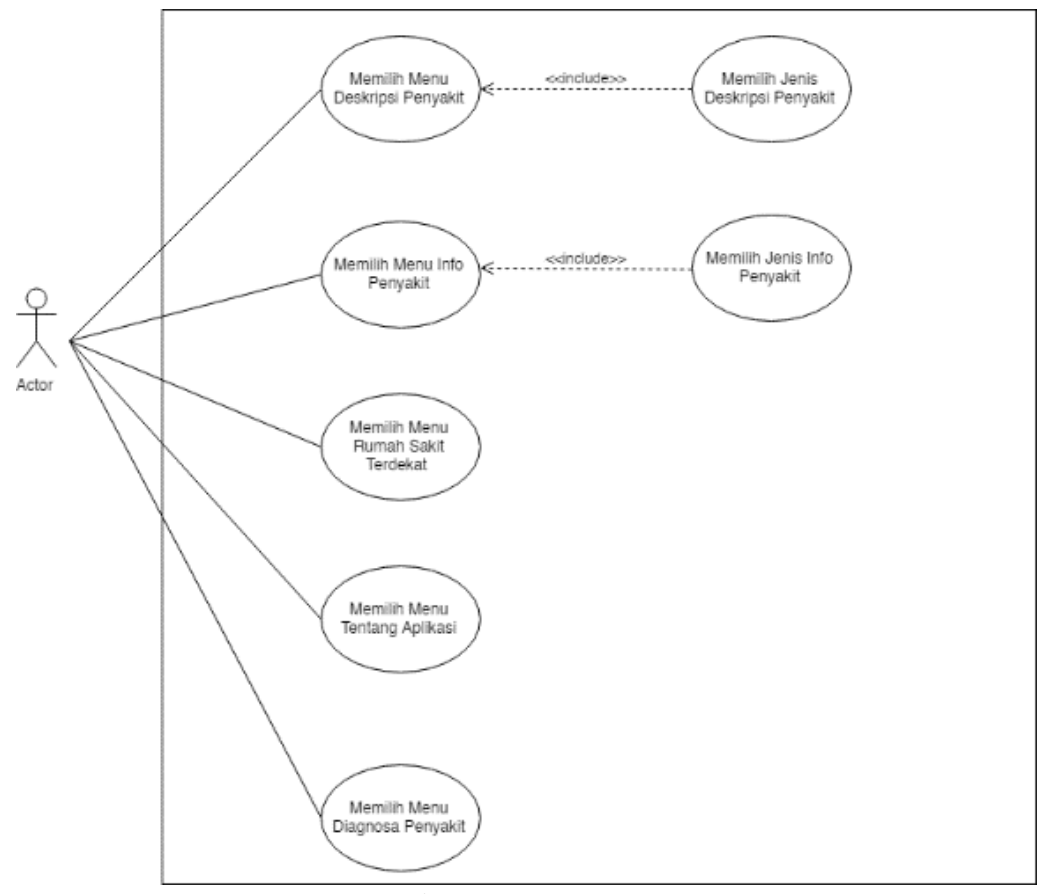

Gambar 3. Use Case 
Sequence diagram digunakan untuk menggambarkan interaksi antar objek di dalam dan disekitar sistem yang berupa message yang digambarkan terhadap waktu. Sequence diagram terdiri antara dimensi vertikal (waktu) dan dimensi horizontal (objek-objek yang terkait).

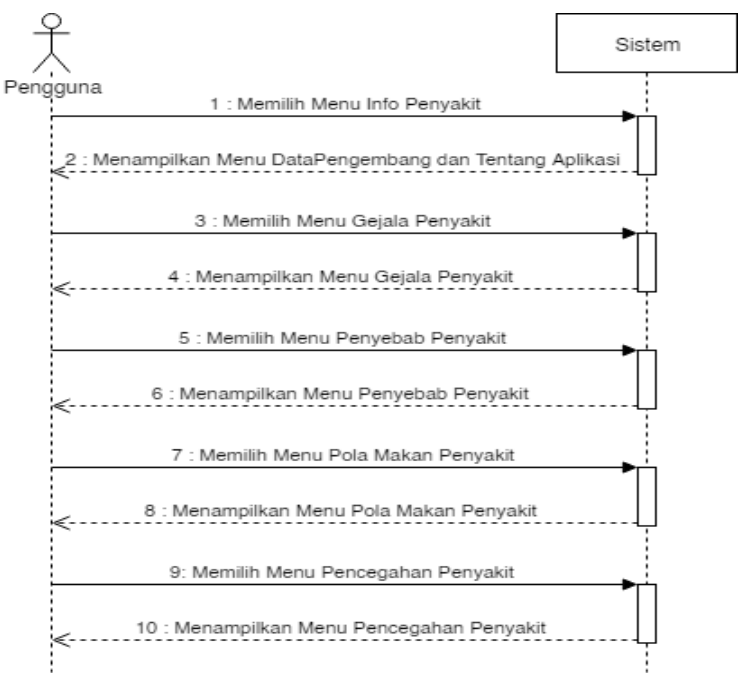

\section{Hasil dan Pembahasan}

Gambar 4. Sequence Diagram

3.1 Pembuatan Aplikasi

Pembuatan aplikasi ini menggunakan metodologi certainty factor. Pada aplikasi ini telah dilakukan uji coba oleh pakar ahli yang berfungsi untuk menunjukkan bahwa gejala yang terdapat pada aplikasi sesuai dengan hasil deteksi serta validasi kesesuaian daftar gejala dan penyakit dengan hasil deteksi Pengujian pakar pada aplikasi sistem pakar Gastritis dilakukan secara objektif yaitu aplikasi diuji secara langsung oleh pakar yaitu dr. Kuadiharto, Sp.PD.FINASIM merupakan dokter spesialis penyakit dalam di Rumah Sakit Umum Daerah Salatiga. Berikut ini adalah form pengujian pakar yang telah diisi oleh pakar dapat ditunjukkan pada Gambar 5.

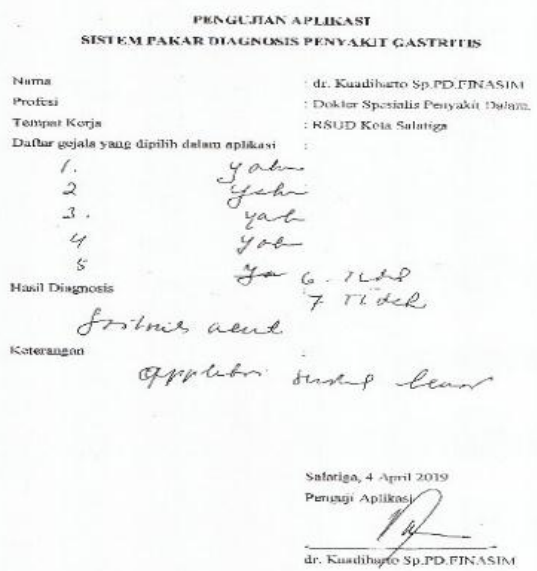

Gambar 5. Form Pengujian oleh Pakar

TRANSFORMATIKA Vol. 18, No. 2, July 2020: $36-55$ 
Gambar 5 menunjukkan hasil dari pengujian pakar dari aplikasi sistem pakar Gastritis. Hasil pengujian dapat disimpulkan bahwa daftar gejala dan hasil penyakit sudah sesuai dengan rekomendasi dari pakar.

Pada Kasus Pertama yaitu ketika dr. Kuadiharto, Sp.PD.FINASIM memilih gejala mengkonsumsi obat dosis tinggi (bukan obat gastritis), mual dan muntah, kondisi badan pucat, perut terasa sakit ketika kosong, dan sering bersendawa. Dari daftar gejala yang dipilih tersebut, maka menghasilkan Tabel keputusan. Berikut merupakan tabel keputusan dari gejala yang dipilih oleh dokter dalam pengujian aplikasi sesuai dengan pengetahuan pakar. Dapat dilihat pada Tabel 6 sebagai berikut.

Tabel 6. Tabel Keputusan Pengujian Pertama

\begin{tabular}{cccc}
\hline $\begin{array}{c}\text { Urutan } \\
\text { Gejala }\end{array}$ & Nama Gejala & \multicolumn{2}{c}{ Nilai CF Gejala } \\
\hline 1 & $\begin{array}{c}\text { Mengkonsumsi obat dosis tinggi } \\
\text { (bukan obat gastritis) }\end{array}$ & C01 & C02 \\
\hline 2 & Mual dan muntah & 0.6 & 0.6 \\
3 & Kondisi badan pucat & 0.4 & 0.6 \\
4 & Perut terasa sakit ketika kosong & 0.6 & 0.6 \\
5 & Sering bersendawa & 0.4 & 0.4 \\
\hline
\end{tabular}

Tabel 6 menunjukkan jika gejala mengkonsumsi obat dosis tinggi(bukan obat gastritis) dimiliki oleh penyakit gastritis akut (C01) dan penyakit gastritis kronis (C02) kemudian gejala mual dan muntah dimiliki oleh penyakit gastritis akut (C01) dan penyakit gastritis kronis(C02), lalu gejala kondisi badan pucat, perut terasa sakit ketika kosong dan sering bersendawa juga sam dimiliki oleh penyakit gastritis akut (C01) dan penyakit gastritis kronis (C02). Jadi bisa disimpulkan dari kedua penyakit sama sama memiliki gejala yang sama tetapi memiliki nilai CF yang berbeda beda. Untuk perhitungannya digunakan rumus sebagai berikut, dikarenakan penyakit yang dipilih memiliki gejala lebih dari satu

Dengan:

$$
\text { CFcombineCF }[H, E]_{1,2}=C F[H, E] 1+C F[H, E] 2 \times\left(1-[H,]_{1}\right)
$$

- CFcombine $C[H, E]_{1,2}$ : nilai Certainty Factor yang memiliki gejala 1 dan 2 pada suatu penyakit.

- $\mathrm{CF}[\mathrm{H}] 1$ : nilai Certainty Factor suatu penyakit yang diberikan oleh pakar dengan gejala 1

- $\mathrm{CF}[\mathrm{H}] 2$ : nilai Certainty Factor suatu penyakit yang diberikan oleh pakar dengan gejala 2

Jadi, perhitungan manualnya sebagai berikut.

a. $\quad$ Mencari nilai $\mathrm{CF}$ untuk penyakit gastritis akut $\left(\mathrm{CF}_{\mathrm{C} 01}\right)$ :

$$
\begin{aligned}
\mathrm{A} & =\mathrm{CF}_{\text {combine }} \mathrm{CFC} 01[\mathrm{H}, \mathrm{E}] 1,2 \\
& =\mathrm{CFC} 01[\mathrm{H}, \mathrm{E}] 1+\mathrm{CFC} 01[\mathrm{H}, \mathrm{E}] 2 \times(1-\mathrm{CFC} 01[\mathrm{H}, \mathrm{E}] 1) \\
& =0,6+0,8 \times(1-0,6) \\
& =0,6+0,8 \times 0,4 \\
& =0,6+0,32 \\
& =0,92 \\
\mathrm{~B} & =\mathrm{CF} \text { combine } \mathrm{CFC} 01[\mathrm{H}, \mathrm{E}] \mathrm{A}, 3 \\
& =\mathrm{CFC} 01[\mathrm{H}, \mathrm{E}] \mathrm{A}+\mathrm{CFC} 01[\mathrm{H}, \mathrm{E}] 3 \times(1-\mathrm{CFC} 01[\mathrm{H}, \mathrm{E}] \mathrm{A}) \\
& =0,92+0,4 \times(1-0,92) \\
& =0,92+0,4 \times 0,08 \\
& =0,92+0,032 \\
& =0,952
\end{aligned}
$$




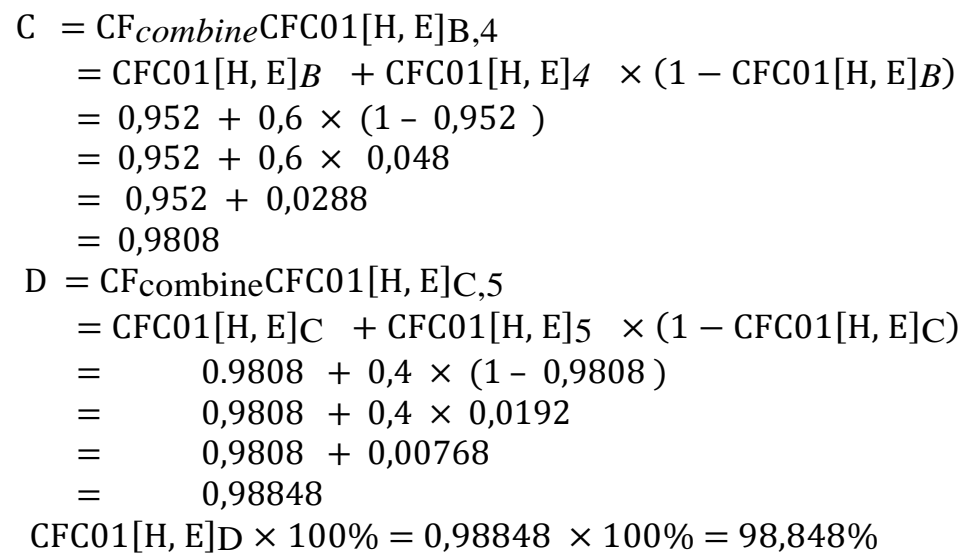

b. Mencari nilai $\mathrm{CF}$ untuk penyakit gastritis akut (CF C01) :

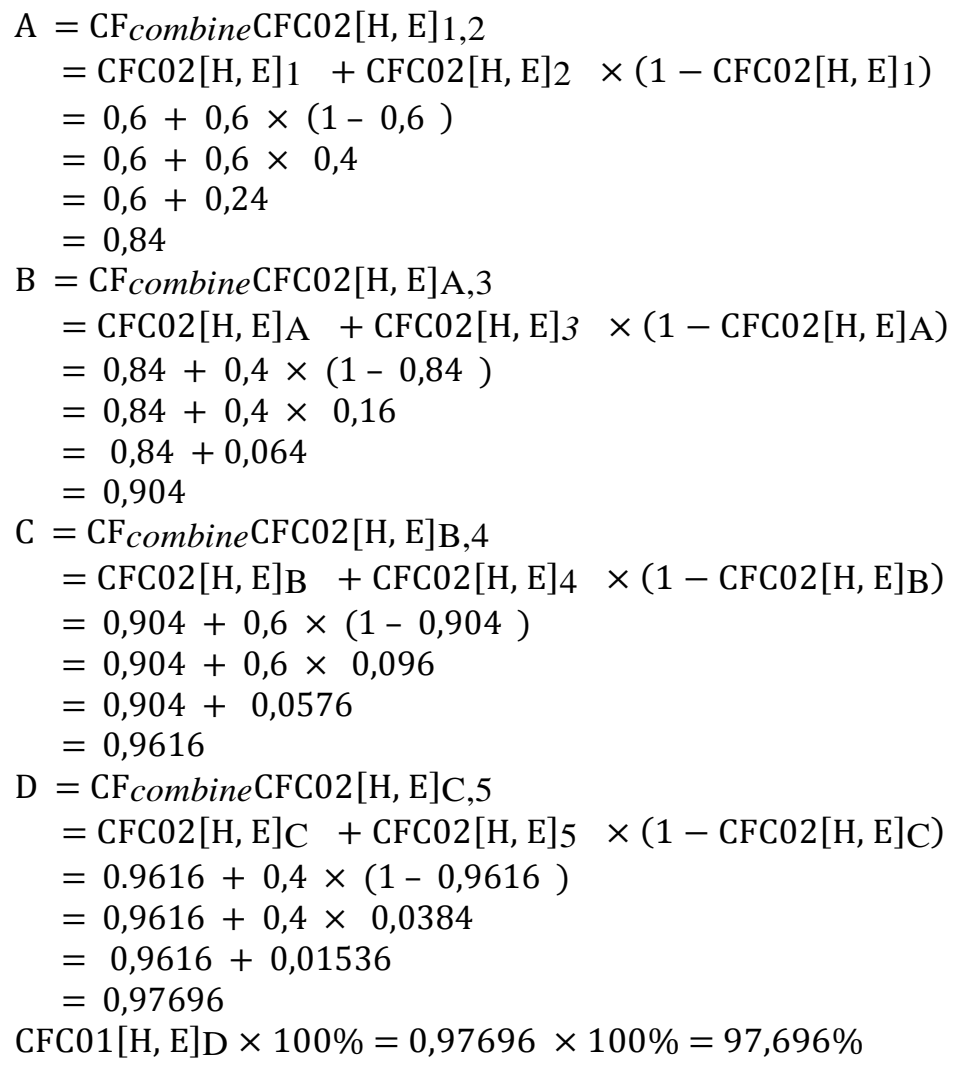

Hasil perhitungan Certainty Factor pada penyakit C01 (Gastritis Akut) memiliki nilai persentase $98,848 \%$ sedangkan pada penyakit C02 (Gastritis Kronis) memiliki nilai persentase 97,696\%. Dengan hasil perhitungan diatas dapat dlihat bahwa paling besar nilai presentasinya adalah penyakit C01 sebesar 98,848\%. Hal ini dibuktikan dengan Gambar 6.

TRANSFORMATIKA Vol. 18, No. 2

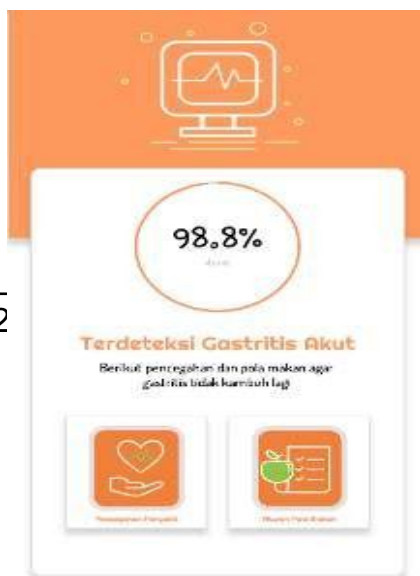


Gambar 6. Hasil perhitungan deteksi pengujian pertama pada sistem aplikasi

Aplikasi hanya menampilkan nilai hasil perhitungan yang paling besar diantara 2 jenis penyakit diatas. Hasil dari perhitungan manual tersebut sama dengan hasil perhitungan pada sistem aplikasi dengan hanya memperlihatkan satu angka dibelakang koma.

Pada Kasus Pengujian kedua yaitu ketika dr. Kuadiharto, Sp.PD.FINASIM memilih gejala mengkonsumsi obat dosis tinggi (bukan obat gastritis), kondisi badan pucat, Nyeri yang terasa panas dan perih di perut bagian ulu hati, Kehilangan selera makan, Muntah Darah, Nyeri pada perut lebih dari 6 bulan dan Susah bernafas. Dari daftar gejala yang dipilih tersebut, maka menghasilkan Tabel keputusan 7 di bawah ini.

Tabel 7. Tabel Keputusan Pengujian Kedua

\begin{tabular}{|c|c|c|c|}
\hline \multirow{2}{*}{$\begin{array}{l}\text { Urutan } \\
\text { Gejala }\end{array}$} & \multirow{2}{*}{ Nama Gejala } & \multicolumn{2}{|c|}{ Nilai CF Gejala } \\
\hline & & C01 & $\mathrm{CO2}$ \\
\hline 1 & $\begin{array}{l}\text { Mengkonsumsi obat dosis tinggi } \\
\text { (bukan obat gastritis) }\end{array}$ & 0.6 & 0.6 \\
\hline 2 & Kondisi badan pucat & 0.4 & 0.4 \\
\hline 3 & $\begin{array}{l}\text { Nyeri yang terasa panas dan perih } \\
\text { di perut bagian ulu hati }\end{array}$ & 0.6 & 0.8 \\
\hline 4 & Kehilangan selera makan & 0.4 & 0.6 \\
\hline 5 & Muntah Darah & - & 0.6 \\
\hline 6 & $\begin{array}{l}\text { Nyeri pada perut lebih dari } 6 \\
\text { bulan }\end{array}$ & - & 0.8 \\
\hline 7 & Susah bernafas & 0.6 & - \\
\hline
\end{tabular}

Tabel 7 menunjukkan jika gejala mengkonsumsi obat dosis tinggi (bukan obat gastritis) dimiliki oleh penyakit gastritis akut(C01) dan penyakit gastritis kronis(C02) kemudian gejala kondisi badan pucat, nyeri yang terasa panas dan perih di perut bagian ulu hati dan kehilangan selera makan juga dimiliki oleh penyakit gastritis akut(C01) dan penyakit gastritis kronis(C02), sedangkan gejala muntah darah dan nyeri pada perut lebih dari 6 bulan hanya dimiliki oleh jenis penyakit gastritis kronis(C02) kemudian gejala susah bernafas hanya dimiliki oleh jenis penyakit gastritis akut(C01). Jadi, perhitungan manualnya sebagai berikut.

a. Mencari nilai $\mathrm{CF}$ untuk penyakit gastritis akut (C01)

$$
\begin{aligned}
\mathrm{A} & =\mathrm{CF}_{\text {combine }} \mathrm{CFC} 01[\mathrm{H}, \mathrm{E}] 1,2 \\
& =\mathrm{CFC} 01[\mathrm{H}, \mathrm{E}] 1+\mathrm{CFC} 01[\mathrm{H}, \mathrm{E}] 2 \times(1-\mathrm{CFC} 01[\mathrm{H}, \mathrm{E}] 1) \\
& =0,6+0,4 \times(1-0,6) \\
& =0,6+0,4 \times 0,4 \\
& =0,6+0,16 \\
& =0,76 \\
\mathrm{~B} & =\mathrm{CF} \text { combine } \mathrm{CFC} 01[\mathrm{H}, \mathrm{E}] \mathrm{A}, 3 \\
& =\mathrm{CFC} 01[\mathrm{H}, \mathrm{E}] \mathrm{A}+\mathrm{CFC} 01[\mathrm{H}, \mathrm{E}] 3 \times(1-\mathrm{CFC} 01[\mathrm{H}, \mathrm{E}] \mathrm{A}) \\
& =0,76+0,6 \times(1-0,76) \\
& =0,76+0,6 \times 0,24 \\
& =0,76+0,144 \\
& =0,904 \\
\mathrm{C} & =\mathrm{CF} \text { combine } \mathrm{CFC} 01[\mathrm{H}, \mathrm{E}] \mathrm{B}, 4
\end{aligned}
$$




$$
\begin{aligned}
& =\mathrm{CFC} 01[\mathrm{H}, \mathrm{E}] \mathrm{B}+\mathrm{CFC} 01[\mathrm{H}, \mathrm{E}] 4 \times(1-\mathrm{CFC} 01[\mathrm{H}, \mathrm{E}] \mathrm{B}) \\
& =0,904+0,4 \times(1-0,904) \\
& =0,904+0,4 \times 0,096 \\
& =0,904+0,0384 \\
& =0,9424 \\
\mathrm{D} & ={ } \mathrm{CF} \text { combine } \mathrm{CFC} 01[\mathrm{H}, \mathrm{E}] \mathrm{C}, 7 \\
& =\mathrm{CFC} 01[\mathrm{H}, \mathrm{E}] \mathrm{C}+\mathrm{CFC} 01[\mathrm{H}, \mathrm{E}] 7 \times(1-\mathrm{CFC} 01[\mathrm{H}, \mathrm{E}] \mathrm{C}) \\
& =0,9424+0,6 \times(1-0,9424) \\
& =0,9424+0,6 \times 0,0576 \\
& =0,9424+0,03456 \\
& =0,97696
\end{aligned}
$$

$\mathrm{CFC} 01[\mathrm{H}, \mathrm{E}] \mathrm{D} \times 100 \%=0,97696 \times 100 \%=97,696 \%$

b. Mencari nilai $\mathrm{CF}$ untuk penyakit gastritis kronis (C02)

$$
\begin{aligned}
& \mathrm{A}=\mathrm{CF} \text { combine } \mathrm{CFC02}[\mathrm{H}, \mathrm{E}] 1,2 \\
& =\mathrm{CFCO} 2[\mathrm{H}, \mathrm{E}] 1+\mathrm{CFC0} 2[\mathrm{H}, \mathrm{E}] 2 \times(1-\mathrm{CFC} 02[\mathrm{H}, \mathrm{E}] 1) \\
& =0,6+0,4 \times(1-0,6) \\
& =0,6+0,4 \times 0,4 \\
& =0,6+0,16 \\
& =0,76 \\
& \mathrm{~B}=\mathrm{CF}_{\text {combine }} \mathrm{CFC02}[\mathrm{H}, \mathrm{E}] \mathrm{A}, 3 \\
& =\mathrm{CFCO} 2[\mathrm{H}, \mathrm{E}] \mathrm{A}+\mathrm{CFCO} 2[\mathrm{H}, \mathrm{E}] 3 \times(1-\mathrm{CFC} 02[\mathrm{H}, \mathrm{E}] \mathrm{A}) \\
& =0,76+0,8 \times(1-0,76) \\
& =0,76+0,8 \times 0,24 \\
& =0,76+0,192 \\
& =0,952 \\
& \mathrm{C}=\mathrm{CF}_{\text {combine }} \mathrm{CFC} 02[\mathrm{H}, \mathrm{E}] \mathrm{B}, 4 \\
& =\mathrm{CFC02}[\mathrm{H}, \mathrm{E}] \mathrm{B}+\mathrm{CFC0} 2[\mathrm{H}, \mathrm{E}] 4 \times(1-\mathrm{CFC} 02[\mathrm{H}, \mathrm{E}] \mathrm{B}) \\
& =0,952+0,6 \times(1-0,952) \\
& =0,952+0,6 \times 0,048 \\
& =0,952+0,0288 \\
& =0,9808 \\
& \mathrm{D}=\mathrm{CF}_{\text {combineCFC02 }[\mathrm{H}, \mathrm{E}] \mathrm{C}, 5} \\
& =\mathrm{CFC0} 2[\mathrm{H}, \mathrm{E}] \mathrm{C}+\mathrm{CFC02}[\mathrm{H}, \mathrm{E}] 5 \times(1-\mathrm{CFC} 02[\mathrm{H}, \mathrm{E}] \mathrm{C})
\end{aligned}
$$




$$
\begin{array}{rl} 
& =0,9808+0,6 \times(1-0,9808) \\
& =0,9808+0,6 \times 0,0192 \\
& =0,9808+0,01152 \\
& =0,99232 \\
\mathrm{E} & =\mathrm{CF}_{\text {combine } C F C 02[\mathrm{H}, \mathrm{E}] \mathrm{D}, 6} \\
& =\mathrm{CFC} 02[\mathrm{H}, \mathrm{E}] \mathrm{D}+\mathrm{CFC} 02[\mathrm{H}, \mathrm{E}] 6 \times(1-\mathrm{CFC} 02[\mathrm{H}, \mathrm{E}] \mathrm{D}) \\
& =0,99232+0,8 \times(1-0,99232) \\
& =0,99232+0,8 \times 0,00768 \\
& =0,99232+0,006144 \\
& =0,998464 \\
\mathrm{CFC} & 02[\mathrm{H}, \mathrm{E}] \mathrm{E} \times 100 \%=0,998464 \times 100 \%=99,8464 \%
\end{array}
$$

Hasil perhitungan Certainty Factor pada penyakit C01 (Gastritis Akut) memiliki nilai persentase 97,696\% sedangkan pada penyakit C02 (Gastritis Kronis) memiliki nilai persentase $99,8464 \%$. Dengan hasil perhitungan diatas dapat dlihat bahwa paling besar nilai presentasinya adalah penyakit C02 sebesar 99,8464\%. Dan Aplikasi hanya menampilkan nilai hasil perhitungan yang paling besar diantara 2 jenis penyakit diatas. Hasil dari perhitungan manual tersebut sama dengan hasil perhitungan pada sistem aplikasi dengan hanya memperlihatkan satu angka dibelakang koma. Hal ini dibuktikan dengan Gambar 7.

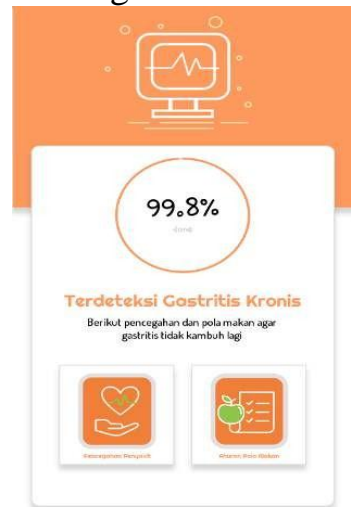

Gambar 7. Hasil perhitungan deteksi pengujian kedua pada sistem aplikasi

Pada Kasus Pengujian ketiga yaitu ketika dr. Kuadiharto, Sp.PD.FINASIM memilih semua gejala penyakit pada aplikasi. Dari daftar gejala yang dipilih tersebut, maka menghasilkan Tabel keputusan yang ditunjukkan pada Tabel 8.

Tabel 8. Tabel Keputusan Pengujian Ketiga

\begin{tabular}{clcc}
\hline $\begin{array}{c}\text { Urutan } \\
\text { Gejala }\end{array}$ & Nama Gejala & $\begin{array}{c}\text { Nilai CF Gejala } \\
\text { C01 }\end{array}$ & C02 \\
\hline 1 & Konsumsi obat dosis tinggi (bukan & 0.6 & 0.6 \\
2 & obat gastritis) & 0.8 & 0.6 \\
3 & Mual dan Muntah & 0.4 & 0.4 \\
4 & Padan Pucat & 0.6 & 0.6 \\
5 & Serut terasa sakit ketika kosong & 0.4 & 0.4 \\
\hline
\end{tabular}




\begin{tabular}{rlcc}
\hline 6 & $\begin{array}{l}\text { Nyeri terasa panas dan perih di } \\
\text { perut bagian ulu hati }\end{array}$ & 0.6 & 0.8 \\
7 & $\begin{array}{l}\text { Buang air besar dengan tinja } \\
\text { berwarna hitam }\end{array}$ & 0.8 & - \\
8 & Perut terasa kembung & 0.4 & 0.4 \\
9 & Kehilangan selera makan & 0.4 & 0.6 \\
10 & Muntah Darah & - & 0.6 \\
11 & Nyeri pada perut lebih dari 6 bulan & - & 0.8 \\
12 & Susah bernafas & 0.6 & - \\
\hline
\end{tabular}

Tabel 8 menunjukkan jika gejala buang air besar dengan tinja berwarna hitam dan susah bernafas hanya dimiliki oleh jenis penyakit gastritis akut (C01) sedangkan gejala muntah darah dan nyeri pada perut lebih dari 6 bulan hanya dimiliki oleh jenis penyakit gastritis kronis (C02) selebihnya gejala pada ke dua jenis penyakit sama tetapi dengan nilai CF yang berbeda. Jadi, perhitungan manualnya sebagai berikut:

a. Mencari nilai $\mathrm{CF}$ untuk penyakit gastritis akut (C01)

$$
\begin{aligned}
& \mathrm{A}=\mathrm{CF} \text { combine } \mathrm{CFC} 01[\mathrm{H}, \mathrm{E}] 1,2 \\
& =\mathrm{CFC} 01[\mathrm{H}, \mathrm{E}] 1+\mathrm{CFC} 01[\mathrm{H}, \mathrm{E}] 2 \times(1-\mathrm{CFC} 01[\mathrm{H}, \mathrm{E}] 1) \\
& =0,6+0,8 \times(1-0,6) \\
& =0,6+0,8 \times 0,4 \\
& =0,6+0,32 \\
& =0,92 \\
& \mathrm{~B}=\mathrm{CF}_{\text {combine }} \mathrm{CFC} 01[\mathrm{H}, \mathrm{E}] \mathrm{A}, 3 \\
& =\mathrm{CFC} 01[\mathrm{H}, \mathrm{E}] \mathrm{A}+\mathrm{CFC} 01[\mathrm{H}, \mathrm{E}] 3 \times(1-\mathrm{CFC} 01[\mathrm{H}, \mathrm{E}] \mathrm{A}) \\
& =0,92+0,4 \times(1-0,92) \\
& =0,92+0,4 \times 0,08 \\
& =0,92+0,032 \\
& =0,952 \\
& \mathrm{C}=\mathrm{CF}_{\text {combine }} \mathrm{CFC} 01[\mathrm{H}, \mathrm{E}] \mathrm{B}, 4 \\
& =\mathrm{CFC} 01[\mathrm{H}, \mathrm{E}] \mathrm{B}+\mathrm{CFC} 01[\mathrm{H}, \mathrm{E}] 4 \times(1-\mathrm{CFC} 01[\mathrm{H}, \mathrm{E}] \mathrm{B}) \\
& =0,952+0,6 \times(1-0,952) \\
& =0,952+0,6 \times 0,048 \\
& =0,952+0,0288 \\
& =0,9808 \\
& \mathrm{D}=\mathrm{CF} \text { combineCFC01[H, E]C,5 } \\
& =\mathrm{CFC} 01[\mathrm{H}, \mathrm{E}] \mathrm{C}+\mathrm{CFC} 01[\mathrm{H}, \mathrm{E}] 5 \times(1-\mathrm{CFC} 01[\mathrm{H}, \mathrm{E}] \mathrm{C}) \\
& =0,9808+0,4 \times(1-0,9808) \\
& =0,9808+0,4 \times 0,0192
\end{aligned}
$$

TRANSFORMATIKA Vol. 18, No. 2, July $2020: 36-55$ 


$$
\begin{array}{rl} 
& =0,9808+0,00768 \\
& =0,98848 \\
\mathrm{E} & =\mathrm{CF} \text { combineCFC01[H, E]D,6 } \\
& =\mathrm{CFC} 01[\mathrm{H}, \mathrm{E}] \mathrm{D}+\mathrm{CFC} 01[\mathrm{H}, \mathrm{E}] 6 \times(1-\mathrm{CFC} 01[\mathrm{H}, \mathrm{E}] \mathrm{D}) \\
& =0,98848+0,6 \times(1-0,98848) \\
& =0,98848+0,6 \times 0,01152 \\
& =0,98848+0,006912 \\
& =0,995392 \\
\mathrm{~F} & =\mathrm{CF} \text { combine } \mathrm{CFC} 01[\mathrm{H}, \mathrm{E}] \mathrm{E}, 7 \\
& =\mathrm{CFC} 01[\mathrm{H}, \mathrm{E}] \mathrm{E}+\mathrm{CFC} 01[\mathrm{H}, \mathrm{E}] 7 \times(1-\mathrm{CFC} 01[\mathrm{H}, \mathrm{E}] \mathrm{E}) \\
& =0,995392+0,8 \times(1-0,995392) \\
& =0,995392+0,8 \times 0,004608 \\
& =0,995392+0,0036864 \\
& =0,9990784 \\
\mathrm{G} & =\mathrm{CF} \text { combine } \mathrm{CFC} 01[\mathrm{H}, \mathrm{E}] \mathrm{F}, 8 \\
& =\mathrm{CFC} 01[\mathrm{H}, \mathrm{E}] \mathrm{F}+\mathrm{CFC} 01[\mathrm{H}, \mathrm{E}] 8 \times(1-\mathrm{CFC} 01[\mathrm{H}, \mathrm{E}] \mathrm{F}) \\
& =0,9990784+0,4 \times(1-0,9990784) \\
& =0,9990784+0,4 \times 0,0009216 \\
& =0,9990784+0,00036864 \\
& =0,99944704 \\
\mathrm{H}= & \mathrm{CF} \text { combine } \mathrm{CFC} 01[\mathrm{H}, \mathrm{E}] \mathrm{G}, 9 \\
& =\mathrm{CFC} 01[\mathrm{H}, \mathrm{E}] \mathrm{G}+\mathrm{CFC} 01[\mathrm{H}, \mathrm{E}] 9 \times(1-\mathrm{CFC} 01[\mathrm{H}, \mathrm{E}] \mathrm{G}) \\
& =0,99944704+0,4 \times(1-0,99944704) \\
& =0,99944704+0,4 \times 0,00055296 \\
& =0,99944704+0,000221184 \\
& =0,999668224 \\
& =\mathrm{CFC} 01[\mathrm{H}, \mathrm{E}] \mathrm{H}+\mathrm{CFC} 01[\mathrm{H}, \mathrm{E}] 12 \times(1-\mathrm{CFC} 01[\mathrm{H}, \mathrm{E}] \mathrm{H}) \\
& =0,999668224+0,6 \times(1-0,999668224) \\
& =0,999668224+0,6 \times 0,000331776 \\
& =0,999668224+0,0001990656 \\
& =0,9998672896 \\
\mathrm{CF} & \mathrm{C} 01[\mathrm{H}, \mathrm{E}] \mathrm{I} \times 100 \%=0,9998672896 \times 100 \%=99,98672896 \% \\
&
\end{array}
$$

b. Mencari nilai $\mathrm{CF}$ untuk penyakit gastritis kronis $(\mathrm{C} 02)$

$$
\begin{aligned}
\mathrm{A} & =\mathrm{CF}_{\text {combine } \mathrm{CFCO} 2[\mathrm{H}, \mathrm{E}] 1,2} \\
& =\mathrm{CFC} 02[\mathrm{H}, \mathrm{E}] 1+\mathrm{CFC} 2[\mathrm{H}, \mathrm{E}] 2 \times(1-\mathrm{CFC} 02[\mathrm{H}, \mathrm{E}] 1) \\
& =0,6+0,6 \times(1-0,6) \\
& =0,6+0,6 \times 0,4 \\
& =0,6+0,24 \\
& =0,84 \\
\mathrm{~B} & =\mathrm{CF} \text { combine } \mathrm{CFC} 02[\mathrm{H}, \mathrm{E}] \mathrm{A}, 3 \\
& =\mathrm{CFC} 02[\mathrm{H}, \mathrm{E}] \mathrm{A}+\mathrm{CFC} 02[\mathrm{H}, \mathrm{E}] 3 \times(1-\mathrm{CFC} 02[\mathrm{H}, \mathrm{E}] \mathrm{A})
\end{aligned}
$$




$$
\begin{aligned}
& =0,84+0,4 \times(1-0,84) \\
& =0,84+0,4 \times 0,16 \\
& =0,84+0,064 \\
& =0,904 \\
& \mathrm{C}=\mathrm{CF}_{\text {combine }} \mathrm{CFC02}[\mathrm{H}, \mathrm{E}] \mathrm{B}, 4 \\
& =\mathrm{CFC} 02[\mathrm{H}, \mathrm{E}] \mathrm{B}+\mathrm{CFC0} 2[\mathrm{H}, \mathrm{E}] 4 \times(1-\mathrm{CFC} 02[\mathrm{H}, \mathrm{E}] \mathrm{B}) \\
& =0,904+0,6 \times(1-0,904) \\
& =0,904+0,6 \times 0,096 \\
& =0,904+0,0576 \\
& =0,9616 \\
& \mathrm{D}=\mathrm{CF}_{\text {combine }} \mathrm{CFC02}[\mathrm{H}, \mathrm{E}] \mathrm{C}, 5 \\
& =\mathrm{CFC} 02[\mathrm{H}, \mathrm{E}] \mathrm{C}+\mathrm{CFC0} 2[\mathrm{H}, \mathrm{E}] 5 \times(1-\mathrm{CFC} 02[\mathrm{H}, \mathrm{E}] \mathrm{C}) \\
& =0,9616+0,4 \times(1-0,9616) \\
& =0,9616+0,4 \times 0,0384 \\
& =0,9616+0,01536 \\
& =0,97696 \\
& \mathrm{E}=\mathrm{CF}_{\text {combine }} \mathrm{CFC02}[\mathrm{H}, \mathrm{E}] \mathrm{D}, 6 \\
& =\mathrm{CFC} 02[\mathrm{H}, \mathrm{E}] \mathrm{D}+\mathrm{CFC02}[\mathrm{H}, \mathrm{E}] 6 \times(1-\mathrm{CFC} 02[\mathrm{H}, \mathrm{E}] \mathrm{D}) \\
& =0,97696+0,8 \times(1-0,97696) \\
& =0,97696+0,8 \times 0,02304 \\
& =0,97696+0,018432 \\
& =0,995392 \\
& \mathrm{~F}=\mathrm{CF}_{\text {combine }} \mathrm{CFC} 02[\mathrm{H}, \mathrm{E}] \mathrm{E}, 8 \\
& =\mathrm{CFC} 02[\mathrm{H}, \mathrm{E}] \mathrm{E}+\mathrm{CFC} 02[\mathrm{H}, \mathrm{E}] 8 \times(1-\mathrm{CFC} 02[\mathrm{H}, \mathrm{E}] \mathrm{E}) \\
& =0,995392+0,4 \times(1-0,995392) \\
& =0,995392+0,4 \times 0,004608 \\
& =0,995392+0,0018432 \\
& =0,9972352 \\
& \mathrm{G}=\mathrm{CF} \text { combine } \mathrm{CFC} 02[\mathrm{H}, \mathrm{E}] \mathrm{F}, 9 \\
& =\mathrm{CFC} 02[\mathrm{H}, \mathrm{E}] \mathrm{F}+\mathrm{CFC} 02[\mathrm{H}, \mathrm{E}] 9 \times(1-\mathrm{CFC0} 2[\mathrm{H}, \mathrm{E}] \mathrm{F}) \\
& =0,9972352+0,6 \times(1-0,9972352) \\
& =0,9972352+0,6 \times 0,0027648 \\
& =0,9972352+0,00165888 \\
& =0,99889408 \\
& \mathrm{H}=\mathrm{CF}_{\text {combine }} \mathrm{CFC02}[\mathrm{H}, \mathrm{E}]_{\mathrm{G}, 10} \\
& =\mathrm{CFC} 02[\mathrm{H}, \mathrm{E}] \mathrm{G}+\mathrm{CFC} 02[\mathrm{H}, \mathrm{E}] 10 \times(1-\mathrm{CFC} 02[\mathrm{H}, \mathrm{E}] \mathrm{G}) \\
& =0,99889408+0,6 \times(1-0,99889408) \\
& =0,99889408+0,6 \times 0,00110592 \\
& =0,99889408+0,000663552 \\
& =0,999557632
\end{aligned}
$$

TRANSFORMATIKA Vol. 18, No. 2, July $2020: 36-55$ 


$$
\begin{aligned}
& \mathrm{I}=\mathrm{CF}_{\text {combine }} \mathrm{CFC} 02[\mathrm{H}, \mathrm{E}] \mathrm{H}, 11 \\
&=\mathrm{CFC} 02[\mathrm{H}, \mathrm{E}] \mathrm{H}+\mathrm{CFC} 02[\mathrm{H}, \mathrm{E}] 11 \times(1-\mathrm{CFC} 02[\mathrm{H}, \mathrm{E}] \mathrm{H}) \\
&=0,999557632+0,8 \times(1-0,999557632) \\
&=0,999557632+0,8 \times 0,000442368 \\
&=0,999557632+0,0003538944 \\
&=0.9999115264 \\
& \mathrm{CFC} 02[\mathrm{H}, \mathrm{E}]_{\mathrm{I}} \times 100 \%=0.9999115264 \times 100 \%=99,99115264 \%
\end{aligned}
$$

Hasil perhitungan Certainty Factor pada penyakit C01 (Gastritis Akut) memiliki nilai persentase 99,98672896\% sedangkan pada penyakit C02 (Gastritis Kronis) memiliki nilai persentase 99,99115264\%. Dengan hasil perhitungan di atas dapat dlihat bahwa paling besar nilai presentasinya adalah jenis penyakit C02 (Gastritis Kronis) sebesar 99,99115264\%. Dan Aplikasi hanya menampilkan nilai hasil perhitungan yang paling besar diantara 2 jenis penyakit diatas. Hasil dari perhitungan manual tersebut sama dengan hasil perhitungan pada sistem aplikasi dengan hanya memperlihatkan satu angka dibelakang koma dan juga dibulatkan ke pembulatan paling tinggi. Hal ini dibuktikan dengan Gambar 8.

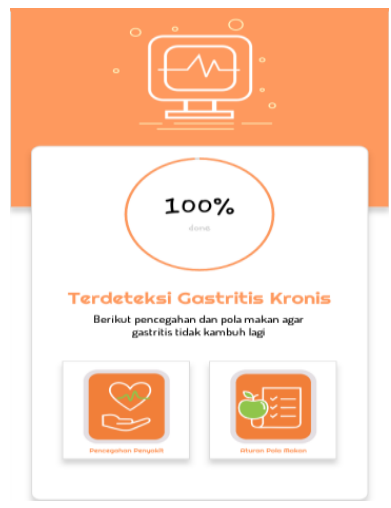

Gambar 8. Hasil perhitungan deteksi pengujian ketiga pada sistem aplikasi

3.2 Pengujian Aplikasi oleh Penderita

Pengujian ini dilakukan terhadap penderita yang sedang mengalami penyakit gastritis yang berjumlah sebanyak 10 orang untuk memastikan apakah aplikasi benar bisa mengidentifikasi jenis penyakit dari gastritis tersebut dan juga untuk mengetahui penilaian terhadap aplikasi yang telah dibuat.

Setiap responden akan diberi 10 sampel pertanyaan dimana setiap pertanyaan terdapat 5 pilihan jawaban, yaitu Sangat Tidak Setuju (STS), Tidak Setuju (TS), Netral (N), Setuju (S), Sangat Setuju (SS). Masing-masing jawaban diberi skor berurutan sampai 5.

Untuk mencari nilai persentase dari masing-masing jawaban kuesioner, digunakan rumus sebagai berikut:

$$
y=\frac{x}{\text { Skor Ideal }} \times 100 \%
$$

Keterangan :

$\mathrm{x}=$ Jumlah frekuensi dikalikan dengan nilai kategori jawaban

Skor ideal $=$ Nilai tertinggi dikalikan dengan jumlah sampel

$\mathrm{y} \quad=$ Nilai persentase yang dicari 
Tabel 9 sampai dengan Tabel 13 menunjukkan jumlah responden dan juga jumlah responden dikalikan skor dari pertanyaan 1 sampai dengan pertanyaan

5. Kemudian dari jawaban yang sudah ada nilainya tersebut dihitung menggunakan rumus diatas dan didapatkan hasil persentase dari masing masing soal.

Pada Tabel 9 dapat dilihat hasil dari kuesioner dari pertanyaan 1 "Apakah aplikasi sistem pakar diagnosis penyakit gastritis ini membantu anda dalam mengidentifikasi penyakit gastritis?".

Tabel 9. Tabel Pengujian Kuesioner Pertanyaan 1

\begin{tabular}{ccccc}
\hline Pertanyaan & Keterangan & Skor & Responden & $\begin{array}{c}\text { Skor } \times \\
\text { Responden }\end{array}$ \\
\hline \multirow{4}{*}{1} & STS & 1 & 0 & 0 \\
& TS & 2 & 0 & 0 \\
& N & 3 & 0 & 0 \\
& S & 4 & 9 & 36 \\
\hline & SS & 5 & 1 & 5 \\
\hline
\end{tabular}

$$
y=\frac{41}{10 \times 5} \times 100 \%=80 \%
$$

Dari pertanyaan 1 "Apakah aplikasi sistem pakar diagnosa penyakit gastritis ini membantu anda dalam mengidentifikasi penyakit gastritis?". Didapatkan 1 responden menjawab dengan jawaban "Sangat Setuju" dan 9 responden menjawab dengan jawaban "Setuju". Berdasarkan hasil persentase nilai di atas, maka dapat disimpulkan bahwa menurut responden penilaian aplikasi Sistem pakar diagnosis penyakit gastritis membantu dalam mengidentifikasi penyakit gastritis adalah $82 \%$. Pada Tabel 10 dapat dilihat hasil dari kuesioner dari pertanyaan 2 "Apakah aplikasi sistem pakar diagnosa penyakit gastritis ini membantu anda dalam menemukan solusi pencegahan pada penyakit gastritis?".

Tabel 10. Tabel Pengujian Kuesioner Pertanyaan 2

\begin{tabular}{ccccc}
\hline Pertanyaan & Keterangan & Skor & Responden & $\begin{array}{c}\text { Skor } \times \\
\text { Responden }\end{array}$ \\
\hline \multirow{2}{*}{2} & STS & 1 & 0 & 0 \\
& TS & 2 & 0 & 0 \\
& N & 3 & 0 & 0 \\
& S & 4 & 8 & 32 \\
SS & 5 & 2 & 10 \\
\hline
\end{tabular}

$$
y=\frac{42}{10 \times 5} \times 100 \%=84 \%
$$

Dari pertanyaan 2 "Apakah aplikasi sistem pakar diagnosa penyakit gastritis ini membantu anda dalam menemukan solusi pencegahan pada penyakit gastritis?". Didapatkan 2 responden menjawab dengan jawaban "Sangat Setuju", 8 responden menjawab dengan jawaban TRANSFORMATIKA Vol. 18, No. 2, July $2020: 36-55$ 
"Setuju". Berdasarkan hasil persentase nilai di atas, maka dapat disimpulkan bahwa menurut responden penilaian aplikasi Sistem pakar diagnosis penyakit gastritis ini sudah membantu dalam menemukan solusi pencegahan adalah $84 \%$.

Pada Tabel 11 dapat dilihat hasil dari kuesioner dari pertanyaan 3 "Apakah menu menu yang ada pada sistem pakar diagnosa penyakit gastritis ini mudah dipahami dan mudah digunakan?".

Tabel 11. Tabel Pengujian Kuesioner Pertanyaan 3

\begin{tabular}{ccccc}
\hline Pertanyaan & Keterangan & Skor & Responden & $\begin{array}{c}\text { Skor } \times \\
\text { Responden }\end{array}$ \\
\hline \multirow{3}{*}{3} & STS & 1 & 0 & 0 \\
TS & 2 & 0 & 0 \\
& N & 3 & 1 & 3 \\
& S & 4 & 6 & 24 \\
SS & 5 & 3 & 15 \\
\hline \multicolumn{4}{c}{$y=\frac{42}{10 \times 5} \times 100 \%=84 \%$} \\
\end{tabular}

Dari pertanyaan 3 "Apakah menu menu yang ada pada sistem pakar diagnosa penyakit gastritis ini mudah dipahami dan mudah digunakan ?". Didapatkan 1 responden menjawab dengan jawaban "Netral", 6 responden menjawab dengan jawaban "Setuju" dan 3 responden menjawab dengan jawaban "Sangat Setuju". Berdasarkan hasil persentase nilai di atas, maka dapat disimpulkan bahwa menurut responden menu menu yang ada pada sistem pakar diagnosa penyakit gastritis ini mudah dipahami dan mudah digunakan adalah $84 \%$.

Pada Tabel 12 dapat dilihat hasil dari kuesioner dari pertanyaan 4 "Apakah informasi yang ada pada sistem pakar ini mudah dimengerti?".

Tabel 12. Tabel Pengujian Kuesioner Pertanyaan 4

\begin{tabular}{ccccc}
\hline Pertanyaan & Keterangan & Skor & Responden & $\begin{array}{c}\text { Skor } \times \\
\text { Responden }\end{array}$ \\
& STS & 1 & 0 & 0 \\
4 & TS & 2 & 0 & 0 \\
N & 3 & 0 & 0 \\
& S & 4 & 6 & 24 \\
& SS & 5 & 4 & 20 \\
\hline & Jumlah & & 10 & 44 \\
\hline
\end{tabular}

$$
y=\frac{44}{10 \times 5} \times 100 \%=88 \%
$$

Dari pertanyaan 4 "Apakah informasi yang ada pada sistem pakar ini mudah dimengerti?". Didapatkan 4 responden menjawab dengan jawaban "Setuju", 6 responden menjawab dengan jawaban "Sangat Setuju". Berdasarkan hasil persentase nilai di atas, maka dapat disimpulkan bahwa menurut responden informasi yang ada pada sistem pakar ini mudah dimengerti adalah $88 \%$. 
Pada Tabel 13 dapat dilihat hasil dari kuesioner dari pertanyaan 5 "Apakah user interface pada aplikasi sistem pakar diagnosa gastritis ini menarik?”.

Tabel 13. Tabel Pengujian Kuesioner Pertanyaan 5.

\begin{tabular}{ccccc}
\hline Pertanyaan & Keterangan & Skor & Responden & $\begin{array}{c}\text { Skor } \times \\
\text { Responden }\end{array}$ \\
\hline \multirow{4}{*}{5} & STS & 1 & 0 & 0 \\
& TS & 2 & 0 & 0 \\
& N & 3 & 0 & 0 \\
& S & 4 & 2 & 8 \\
& SS & 5 & 8 & 40 \\
\hline
\end{tabular}

$$
y=\frac{48}{10 \times 5} \times 100 \%=96 \%
$$

Dari pertanyaan 5 "Apakah user interface pada aplikasi sistem pakar diagnosa gastritis ini menarik?". Didapatkan 2 responden menjawab dengan jawaban "Setuju", 8 responden menjawab dengan jawaban "Sangat Setuju". Berdasarkan hasil persentase nilai di atas, maka dapat disimpulkan bahwa menurut responden penilaian user interface pada aplikasi sistem pakar diagnosa gastritis ini menarik adalah $96 \%$.

Pada Tabel 13 dapat dilihat hasil masing-masing dari pertanyaan yang terdapat pada kuesioner dan telah diberikan kepada 10 responden.

Tabel 13. Tabel Jumlah Persentase Tiap Pertanyaan

\begin{tabular}{cc}
\hline Pertanyaan & $\begin{array}{c}\text { Persentase Jumlah } \\
\text { Tiap Pertanyaan }\end{array}$ \\
1 & $82 \%$ \\
2 & $84 \%$ \\
3 & $84 \%$ \\
4 & $88 \%$ \\
5 & $96 \%$ \\
\hline Jumlah & $434 \%$ \\
\hline
\end{tabular}

Untuk mencari nilai persentase dari keseluruhan jawaban kuesioner, digunakan rumus rata-rata (mean) sebagai berikut:

Keterangan :

$$
\overline{\mathrm{x}}=\frac{\mathrm{x}_{1}+\mathrm{x}_{2}+\ldots+\mathrm{x}_{\mathrm{n}}}{n}
$$

$$
\begin{aligned}
& \overline{\mathrm{x}} \quad=\text { Rata-rata hitung } \\
& \mathrm{x}_{\mathrm{n}} \quad=\text { Nilai sampel ke-n } \\
& \mathrm{n} \quad=\text { Jumlah sampel }
\end{aligned}
$$

$$
\bar{x}=\frac{434 \%}{5}=86.8 \%
$$

\section{Kesimpulan}

Metode Certainty Factor memberikan proses diagnosis dengan nilai CF gejala yang telah ditentukan oleh pakar sehingga memberikan hasil yang akurat dari perhitungan berdasarkan nilai

TRANSFORMATIKA Vol. 18, No. 2, July 2020: $36-55$ 
CF gejala yang telah dipilih oleh pengguna. Berdasarkan hasil pengujian aplikasi Sistem Pakar Diagnosis Penyakit Gastritis menggunakan olahan data kuesioner menunjukkan bahwa $86.8 \%$ lebih responden menjawab dengan jawaban positif atau dapat dikatakan aplikasi ini sudah berhasil dengan baik mengidentifikasi penyakit.

Berdasarkan hasil pengujian yang dilakukan oleh pakar menunjukkan bahwa hasil diagnosis oleh sistem menampilkan nilai persentase keyakinan terhadap kebenaran deteksi dengan nilai persentase kasus pengujian pertama 98,848\%, kasus pengujian kedua 99,8464\% dan kasus pengujian ketiga 99,99115264\%.

\section{Daftar Pustaka}

[1] Z. Gu, H.-Q. Shen, P.-H. Fu, and M. Chen, "Screening of long non-coding RNAs markers in plasma of children with chronic gastritis," Chronic Dis. Transl. Med., vol. 6, no. 1, pp. 62-68, 2020.

[2] M. D. Naomi Uemura, M.D., Shiro Okamoto, M.D., Soichiro Yamamoto, M.D., Nobutoshi Matsumura, M.D., Shuji Yamaguchi, M.D., Michio Yamakido, M.D., Kiyomi Taniyama, M.D., Naomi Sasaki, M.D., and Ronald J. Schlemper, "Helicobacter pylori Infection and the Development of Gastric Cancer," N. Engl. J. Med., vol. 345, no. 11, pp. 784-789, 2001.

[3] J. H. Song, S. G. Kim, E. H. Jin, J. H. Lim, and S. Y. Yang, "Risk factors for gastric tumorigenesis in underlying gastric mucosal atrophy," Gut Liver, vol. 11, no. 5, pp. 612619, 2017.

[4] D. Y. Cheung, "Atrophic gastritis increases the risk of gastric cancer in asymptomatic population in Korea," Gut Liver, vol. 11, no. 5, pp. 575-576, 2017, doi: $10.5009 / \mathrm{gn} l 17356$.

[5] Y. J. Hwang et al., "Reversibility of atrophic gastritis and intestinal metaplasia after Helicobacter pylori eradication - a prospective study for up to 10 years," Aliment. Pharmacol. Ther., vol. 47, no. 3, pp. 380-390, 2018.

[6] M. Joo, "Rare gastric lesions associated with Helicobacter Pylori infection: A histopathological review," J. Pathol. Transl. Med., vol. 51, no. 4, pp. 341-351, 2017.

[7] M. Mohammadi, A. Talebi Bezmin Abadi, F. Rahimi, and M. Forootan, "Helicobacter heilmannii Colonization Is Associated With High Risk for Gastritis," Arch. Med. Res., vol. 50, no. 7, pp. 423-427, 2019.

[8] S. D. Altindag, E. Cakir, N. Ekinci, A. Avci, and F. H. Dilek, "Analysis of clinical and histopathological findings in Russell body gastritis and duodenitis," Ann. Diagn. Pathol., vol. 40, pp. 66-71, 2019.

[9] E. Ha and J. H. Bae, "Zinc transporter SLC39A11 polymorphisms are associated with chronic gastritis in the Korean population: the possible effect on spicy food intake," Nutr. Res., vol. 57, pp. 78-85, 2018.

[10] E. Chojnacki, W. Plumecocq, and L. Audouin, "An expert system based on a Bayesian network for fire safety analysis in nuclear area," Fire Saf. J., vol. 105, no. February, pp. 28-40, 2019.

[11] I. G. Damousis, D. Tzovaras, and M. G. Strintzis, "A fuzzy expert system for the early warning of accidents due to driver hypo-vigilance," Pers. Ubiquitous Comput., vol. 13, no. 1, pp. 43-49, 2009.

[12] J. Li and Y. Zhang, "GIS-supported certainty factor (CF) models for assessment of geothermal potential: A case study of Tengchong County, southwest China," Energy, vol. 140, pp. 552-565, 2017.

[13] L. A. Latumakulita, "Sistem Pakar Pendiagnosa Penyakit Anak Menggunakan Certainty Factor (Cf)," J. Ilm. Sains, vol. 12, no. 2, p. 120, 2012. 